\title{
49. VØRING PLATEAU VOLCANIC MARGIN: EXTENSION, MELTING, AND UPLIFT ${ }^{1}$
}

\author{
Tom Pedersen and Jakob Skogseid ${ }^{2}$
}

\begin{abstract}
Seismic sections and ODP drilling information at the Vøring Plateau volcanic passive margin have provided the framework for modeling the generation of basaltic magma and uplift associated with the early Tertiary rifting event. A simple uniform lithosphere stretching model of subsidence, incorporating partial melting in the upper mantle, accounts for both the volume of liquid basalt produced and the amount of uplift, when a minor temperature excess of approximately $50^{\circ} \mathrm{C}$ is assumed at the base of the lithosphere.
\end{abstract}

\section{INTRODUCTION}

The early Tertiary breakup in the North Atlantic from Hatton Bank to the Arctic Ocean was associated with significantly increased volcanic activity. This event is documented by the North Atlantic Volcanic Province (NAVP) and huge volcanic edifices beneath segments of the present outer continental margin. These features, often forming marginal highs and exhibiting seaward-dipping reflector sequences, have lately been characterized as "volcanic" passive margins. These margins, drilled during DSDP Leg 81 (Roberts, Schnitker et al., 1984) and ODP Leg 104 (Eldholm, Thiede, Taylor et al., 1987), have provided critical information regarding their evolution.

The drilling at the Voring Plateau proved that the volcanic rocks were emplaced subaerially or at shallow water depth (Eldholm, Thiede, Taylor et al., 1987). This suggests an absence of initial subsidence associated with the final phase of rifting, which left the outer margin emergent without appreciable sedimentation several million years after the start of sea-floor spreading.

A number of evolutionary models have been suggested, primarily to explain the dipping reflector wedges seaward of the Voring Plateau and Faeroe-Shetland escarpments and at the Hatton Bank margin (Hinz, 1981; Hinz et al., 1984; Morton and Taylor, 1987; Mutter et al., 1982, 1984; Roberts et al., 1984; Smythe, 1983). However, few models have attempted to discuss the volcanic margin history in terms of the pre-Cenozoic evolution and the relationship with the NAVP (Skogseid and Eldholm, 1987; Eldholm, Thiede, Taylor, and Shipboard Scientific Party et al., 1987). The various models, which are discussed by Eldholm et al., this volume), differ principally with respect to the location of the continent/ocean boundary and the nature of the crust below the main seaward-dipping wedge.

Recently, expanding spread profiling (ESP) experiments have documented an increased crustal thickness beneath the Vøring Plateau marginal high (Mutter et al., 1984; Hinz et al., 1987) and the Hatton Bank margin (White et al., 1987) that has been interpreted to reflect generation of large amounts of partial melts during rifting.

In this paper we attempt to describe in a quantitative way the formation of basalt flows at the Vøring Plateau. We first derive the varying amount of extension across the Vøring Basin from analysis of the tectonic subsidence inferred from the seismic interpretation of Skogseid and Eldholm (this volume). The vol-

\footnotetext{
${ }^{1}$ Eldholm, O., Thiede, J., Taylor, E., et al., 1989. Proc. ODP, Sci. Results, 104: College Station, TX (Ocean Drilling Program).

2 Department of Geology, University of Oslo, P.O. Box 1047, N-0316 Blindern, Oslo, Norway.
}

ume of liquid basalt that can be produced during rifting and the amount of uplift is then computed, assuming a simple lithospheric stretching model that incorporates partial melting in the upper mantle beneath the area of lithospheric stretching.

\section{UNIFORM LITHOSPHERIC EXTENSION INCORPORATING PARTIAL MELTING}

Assuming a uniform lithospheric extension model of subsidence (McKenzie, 1978), Le Pichon and Sibuet (1981) and Le Pichon et al. (1982) derived simple expressions for the initial subsidence, $S_{l}$, immediately after the instantaneous stretching event, and the total subsidence, $S_{T}$, when the thermal anomaly associated with the stretching has decayed to a zero value:

and

$$
S_{I}=(3600-E) \cdot(1-1 / \beta)
$$

$$
S_{T}=(7800-E) \cdot(1-1 / \beta)
$$

where $E$ is the initial water depth and $\beta$ is the stretching factor. $E, S_{I}$, and $S_{T}$ are in meters. The thermal subsidence is defined as the difference between the total and initial subsidence, corrected for the finite time since rifting (Le Pichon and Sibuet, 1981). For $\beta$ greater than a critical value, which depends on the thickness and basal temperature of the lithosphere, partial melting occurs as the upper mantle reaches its solidus. This reduces the subsidence given by Eqs. 1 and 2 .

It is generally agreed that the degree of melting varies with depth and temperature (Yoder, 1978; Cox et al., 1979). An analytical expression relating the degree of melting, $f$, to the temperature, $T$, and depth, $z$, was proposed by Ahern and Turcotte (1979):

$$
f=A \cdot(\exp )(B(T-C \cdot z-D))-1)
$$

where $A, B, C$, and $D$ are the constants with values given in Table 1. Adopting this expression, Foucher et al. (1982) have introduced partial melting effects into the uniform stretching model.

Immediately after stretching, the temperature distribution, $T$, as a function of depth, $z$, is given by:

$$
T(z)= \begin{cases}\left(T^{\prime}{ }_{h l} \cdot \frac{\beta}{h l} \cdot z-\frac{f \cdot L}{C_{p}}\right. & \text { for } 0 \leq z \leq \frac{h l}{\beta} \\ T^{\prime}{ }_{h l}+G \cdot\left(z-\frac{h l}{\beta}\right)-\frac{f \cdot L}{C_{\mathrm{p}}} & \text { for } \frac{h l}{\beta} \leq z \leq h l\end{cases}
$$

where $L$ is the latent heat of fusion, $C_{p}$ is the specific heat capacity at constant temperature, $G$ is the adiabatic temperature gradient, and 
Table 1. Model parameters. Based on Foucher et al. (1982) and Parsons and Sclater (1977).

\begin{tabular}{|l|c|l|}
\hline Parameter & & Value \\
\hline Density of water & $\rho_{w}$ & $1000 \mathrm{~kg} \mathrm{~m}^{-3}$ \\
Density of upper mantle at $T_{h l}$ & $\rho_{h l}$ & $3300 \mathrm{~kg} \mathrm{~m} \mathrm{~m}^{-3}$ \\
Density of liquid basalt & $\rho_{a l}$ & $2600 \mathrm{~kg} \mathrm{~m} \mathrm{~m}^{-3}$ \\
Density of sediment grains & $\rho_{g}$ & $2700 \mathrm{~kg} \mathrm{~m} \mathrm{~m}^{-3}$ \\
Adiabatic temperature gradient & $\mathrm{G}$ & $0.0003 \mathrm{~K} \mathrm{~m}$ \\
Constant in Eq. 3 & $\mathrm{A}$ & 0.4 \\
Constant in Eq. 3 & $\mathrm{B}$ & $3.65 \cdot 10^{-3} \mathrm{~K}^{-1}$ \\
Constant in Eq. 3 & $\mathrm{C}$ & $3.0 \cdot 10^{-3} \mathrm{~K} \mathrm{~m} \mathrm{~m}^{-1}$ \\
Constant in Eq. 3 & $\mathrm{D}$ & $1100{ }^{\circ} \mathrm{C}$ \\
Latent heat of fusion & $\mathrm{L}$ & $334000 \mathrm{~J} \mathrm{~kg}$ \\
Specific heat & $C_{p}$ & $1050 \mathrm{~J} \mathrm{~kg} \mathrm{Kg}^{-1}$ \\
Thermal time constant & $\tau$ & $62.8 \mathrm{my}$ \\
\hline
\end{tabular}

$$
T_{h l}=T_{h l}-G \cdot(h l-h l / \beta)
$$

where $T_{h l}$ is the temperature at a depth $h l$, the thermal thickness of the lithosphere. The degree of melting, $f$, and the reduced temperatures (due to melting) are calculated numerically from Eqs. 3 and 4 and the results are shown in Figure 1. The critical depth for the onset of melt generation, $z f$, is obtained by setting $f=0$ in Eq. 3, using the temperature distribution from Eq. 4. Thus,

$$
z f=\frac{T_{h l}-G \cdot h l-D}{C-G} .
$$

Note that $z f$ only depends on the initial conditions of the lithosphere. An important implication of Eq. 6 is that it constrains the maximum temperature at the base of the lithosphere for a given lithospheric thickness.

Knowing $f$ as a function of depth, $z$, the total thickness of liquid basalt produced, $M$, is computed from (Foucher et al., 1982):

$$
M=\frac{\rho_{h l}}{\rho_{a l}} \cdot \int_{o}^{h l} f(z) d z
$$

where $\rho_{h l}$ is the density of upper mantle at $T_{h l}$ and $\rho_{a l}$ is the density of liquid basalt. As $\rho_{a l}$ is less than $\rho_{h l}$ there is a negative correction to the initial subsidence given by:

$$
\Delta S_{I}=\frac{\rho_{h l}}{\rho_{h l}-\rho_{w}} \int_{0}^{h l} \frac{\rho_{a l}-\rho_{\mathrm{hl}}}{\rho_{a l}} f(z) d z .
$$

If there is uplift above sea level, the density of water, $\rho_{w}$, is replaced with 0 .

Finally, Foucher et al. (1982) have shown that the total subsidence after return of the lithosphere to thermal equilibrium is not significantly changed by introducing partial melting into the extension model.

\section{THE VØRING PLATEAU MARGIN}

The Vøring Plateau Margin is located adjacent to the large Vøring Basin (Fig. 2). The sedimentation record of the Vøring Basin reveals repeated phases of tectonism since Devonian times. The tectonic events, dominated by extension, appear to have migrated westward with time (Bukovics et al., 1984; Bukovics and Ziegler, 1985). Commercial drilling has proved more than $2000 \mathrm{~m}$ of Jurassic and Triassic sediments at the Trondelag Platform (Hollander, 1984). Seismic data show that this sedimentary sequence is continued westward, being downfaulted at the adja- cent Halten Terrace and probably also exists in the Traen Basin. The Kimmerian stretching event initiated the regional subsidence of the Vøring Basin. Several local sub-basins such as the Halten Trough, the Traen Basin and the Smøla Rift (Figs. 2 and 3), particular those near the Trøndelag Platform, were rapidly filled by lower Cretaceous sediments, whereas the highs experienced a low rate of sedimentation subsequent to rifting. During the late Cretaceous the regional basin subsided and a thick sequence of upper Cretaceous sediments was deposited. In the seismic data, the early Tertiary opening of the NorwegianGreenland Sea is indicated by detached, rotated fault blocks at the base Tertiary sequence level within the Smøla and Fleina rifts. These fault blocks were eroded, implying uplift relative to the adjacent eastern basin. In a 10 - to $40-\mathrm{km}$ wide zone landward of the Vøring Plateau Escarpment stratigraphic data are available only for the Tertiary sequence, as basalt flows related to the Norwegian-Greenland Sea opening event mask the deeper strata.

Figure 3 shows that the Vøring Plateau marginal high is dominated by a huge wedge of seaward-dipping basalt flows. These flows were emplaced in the earliest Eocene (Eldholm, Thiede, Taylor et al., 1987; LeHuray and Johnson, this volume).

The detatched faulting in the Smøla Rift is evidence that crustal extension took place prior to the early Cenozoic opening of the Norwegian-Greenland Sea (Skogseid and Eldholm, this volume). The faulting was followed by uplift and erosion building up the relatively thick sediment sequence between the base Tertiary $(65 \mathrm{Ma})$ and earliest Eocene $(58 \mathrm{Ma})$ reflectors on the landward side (Fig. 3). Sills are observed crossing the listric fault planes, indicating the intrusions to be slightly younger than the faulting. The sills may be time equivalent with deposition of the first flows overflowing the Vøring Plateau Escarpment into the Vøring Basin. Finally, the earliest Eocene reflector $(58 \mathrm{Ma})$ marks the transition to a regional pattern of subsidence landward of the Vøring Plateau Escarpment. This reflector is associated with a regional tuff marker dated from commercial wells in the North Sea (Knox, 1988). At the Vøring Margin it is related to deposition of volcanic extrusives associated with the early drifting stage, and the eruption and deposition of the sequence of dipping reflectors that was emplaced during a period of maximum 3 m.y. in the earliest Eocene (Skogseid and Eldholm, 1987).

ESP data at the Vøring Plateau show an increased crustal thickness underneath the dipping sequence, and the lower crust exhibits velocities in the range 7.5-7.8 km/s (Mutter et al., 1988). A similar crustal configuration is observed by White et al. (1987) at the Hatton Bank Margin. Hinz et al. (1987), White et al. (1987) and Mutter and Zehnder (1988) assume the 7.5- to $8.0-\mathrm{km} / \mathrm{s}$ velocity body in the lower crust to represent accumulations of melted upper mantle produced during rifting. Thus, this body and the dipping sequence constitute the melt produced during initial opening. We estimate, allowing for some intermediate intrusives, that both the Hatton Bank and the Vøring margin cross sections contain 500 - to $1000-\mathrm{km}^{3}$ per margin length unit.

\section{MODEL APPLICATION AND RESULTS}

Backstripping techniques (e.g., Watts and Ryan, 1976) were used to compute the tectonic subsidence curves at three locations $(3,4$, and 5$)$ along the geological section shown in Fig. 3. The sediment decompaction was performed using the exponential porosity-depth function:

$$
\phi(z)=49 \exp (-0.27 z)
$$

where the porosity $(\phi)$ is in percent and the depth $z$ is in kilometers (Sclater and Christie, 1980). Corrections for water depth 

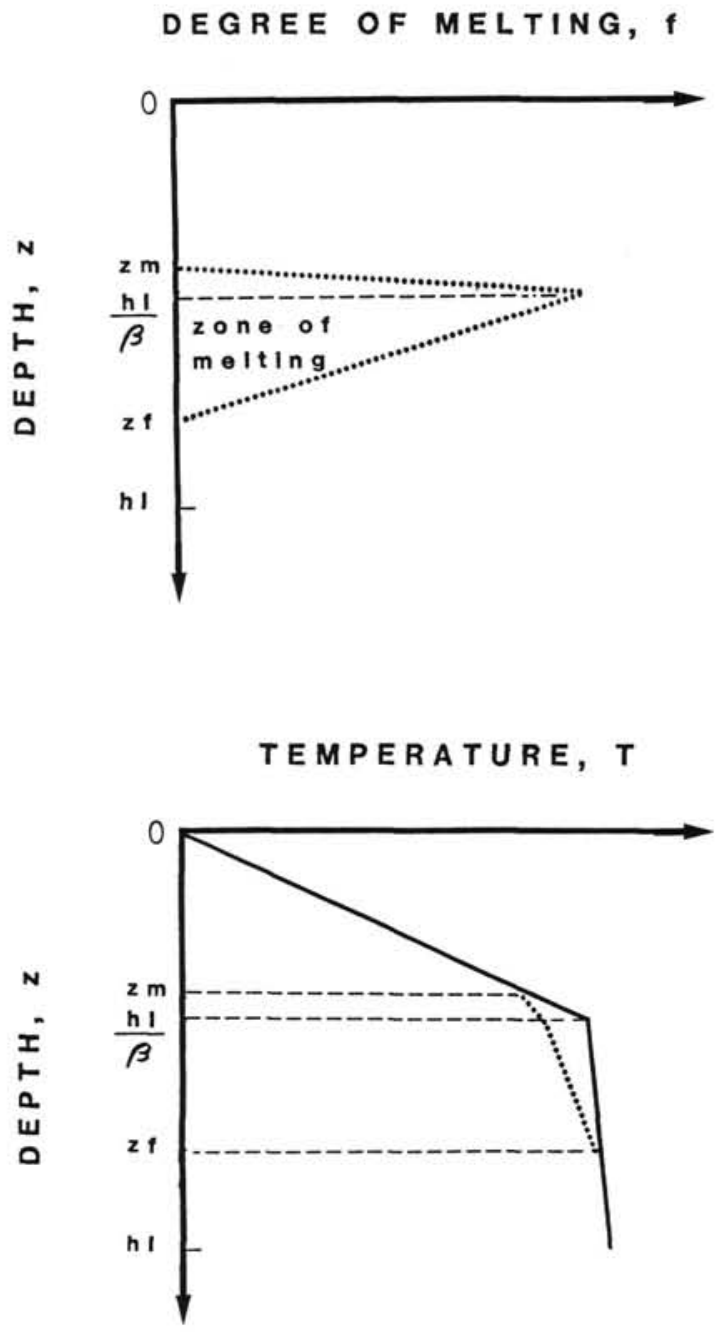

Figure 1. Schematic diagrams for partial melting of the lithosphere based on equations 3 and 4 and the parameters in Table 1. Top: Degree of melting as a function of depth. After uniform instantaneous extension, the initial lithospheric thickness, $h l$, is reduced to $h l / \beta$ where $\beta$ is the stretching factor. The zone of melting lies between $z m$ and $z f$, the critical depth for the onset of melting. Maximum degree of melting occurs at a depth of $h l / \beta$. Bottom: Temperature-depth relationship with (dotted line) and without (solid line) melting. The initial lithospheric thickness, $h l$, is reduced to $h l / \beta$ after stretching. Note there is a small adiabatic temperature gradient in the asthenosphere (between $h 1 / \beta$ and $h l$ ). The temperatures outside the melting zone (extending from $\mathrm{zm}$ to $z f)$ are not affected, whereas they are reduced in the melting zone.

variations were performed using the values given in Table 2. The sediments were unloaded assuming Airy isostasy and using the densities in Table 1. The early Tertiary erosion at location 3 was accounted for by applying the procedure described by Pedersen (1987). An eroded sediment thickness of about $500 \mathrm{~m}$ was estimated from burial history curves (Guidish et al., 1985). This estimate is in agreement with thicknesses inferred from the seismic interpretation $(<800 \mathrm{~m})$. Finally, the age of the sediments below the unconformity is estimated to be $84 \mathrm{Ma}$.

The tectonic subsidence curves presented in Figure 3 for the three different locations across the Vøring Basin show that the early Tertiary phase of extension leading to continental breakup and massive volcanism can be recognized as a distinct event at both locations 3 and 4 . These depths refer, of course, to an unloaded basement level that reflects the earlier tectonic history and do not represent the actual water depths at $65 \mathrm{Ma}$ (cf. Table 2). The water depth at location $4,1890 \mathrm{~m}$, was taken directly from the tectonic subsidence curve (Fig. 3). At location 3, we have estimated a depth of $2430 \mathrm{~m}$ based on the pre-Tertiary subsidence, corrected for the effects of erosion.

Correcting the total subsidence values for the reduction in thermal subsidence due to a finite time since rifting, $\beta$ was calculated to be 1.8 at location 3 and 1.6 at location 4 . Note that these $\beta$ values refer to the early Tertiary stretching event, and not to the total extension the area has experienced.

We adopted a value of 3.3 for the stretching factor at the assumed continent/ocean boundary, location 1 . This is mainly based on theoretical considerations (Le Pichon and Sibuet, 1981; England, 1983; Sawyer, 1985) as it is difficult to obtain an estimate from the actual data. If, however, it is assumed that the prestretching crustal thicknesses at both sides of the Smøla Rift, locations 1 and 4 , were nearly equal, $\beta$ may be computed by dividing the inferred pre-stretching thickness of about $22 \mathrm{~km}$ (obtained by multiplying the $1.6 \beta$ value and the present crustal thickness of $14 \mathrm{~km}$ (Mutter et al., 1988) at location 4) with the present value of $8 \mathrm{~km}$ (Mutter et al., 1988). This gives a stretching factor of approximately 3 . For location 4 we have subtracted the thickness of the sediments whereas for location 1 we have subtracted the thickness of the underplated body $(7.5-7.8 \mathrm{~km} / \mathrm{s})$ and the dipping reflector sequence. Finally, $\beta$ was taken to be 2.5 at the Vøring Plateau Escarpment (2, Fig. 3) by interpolation between 1 and 3, and to approach 1.0 about $200 \mathrm{~km}$ east of location 1 .

The total volume of melt generated was calculated from:

$$
M(\text { total })=\int_{0}^{200} M(x) d z
$$

where $x$ is the distance from location 1 in $\mathrm{km}$. We examined three different lithospheric models, with the lithospheric thickness increasing from $75 \mathrm{~km}$ to $125 \mathrm{~km}$, while the temperature at the base of the lithosphere increases from $1325^{\circ} \mathrm{C}$ to $1445^{\circ} \mathrm{C}$, from model A to C (Fig. 4).

Assuming initial rifting just subsequent to $65 \mathrm{Ma}$, using the initial water depths (2430 and $1890 \mathrm{~m}$ at locations 3 and 4, an estimate of $2000 \mathrm{~m}$ at locations 1 and 2), and the model parameters in Table 1, we calculated the depth to the water-loaded basement along the section for the three lithospheric models (Fig. 5).

Model A shows that the calculated minimum melt volume of $500 \mathrm{~km}^{3}$ may be produced from a $75-\mathrm{km}$ thick lithosphere provided that the temperature at its base is as high as $1325^{\circ} \mathrm{C}$. The model predicts a small relative uplift at locations 1,2 , and 3 and subsidence at 4 . The fit to the computed tectonic subsidence (Fig. 5) at location 3 is poor. As $1325^{\circ} \mathrm{C}$ is the maximum temperature for a $75-\mathrm{km}$ thick lithosphere (cf. Eq. 6), $500 \mathrm{~km}^{3}$ is also the maximum amount of melt that can be produced in model A for the applied $\beta$ distribution. Model B (Fig. 4) shows that a $750-\mathrm{km}^{3}$ volume of melt may be generated from a $100-\mathrm{km}$ thick lithosphere, assuming a basal temperature of about $1385^{\circ} \mathrm{C}$. The fit to the computed tectonic subsidence at location 3 is better in this model, although it implies an excess of uplift at location 4 (Fig. 5). A maximum of $1000 \mathrm{~km}^{3}$ of melt is produced with model C. Using this model, the associated relative uplift is much in excess of what is observed. Thus, we feel that model B, or possibly an intermediate model between A and B, corresponds best with the observed data.

Finally, we earlier pointed out that the water depths in Figure 5 only refer to depths of a waterloaded basement. Figure 3, however, demonstrates that the basin had a thick cover of sedi- 


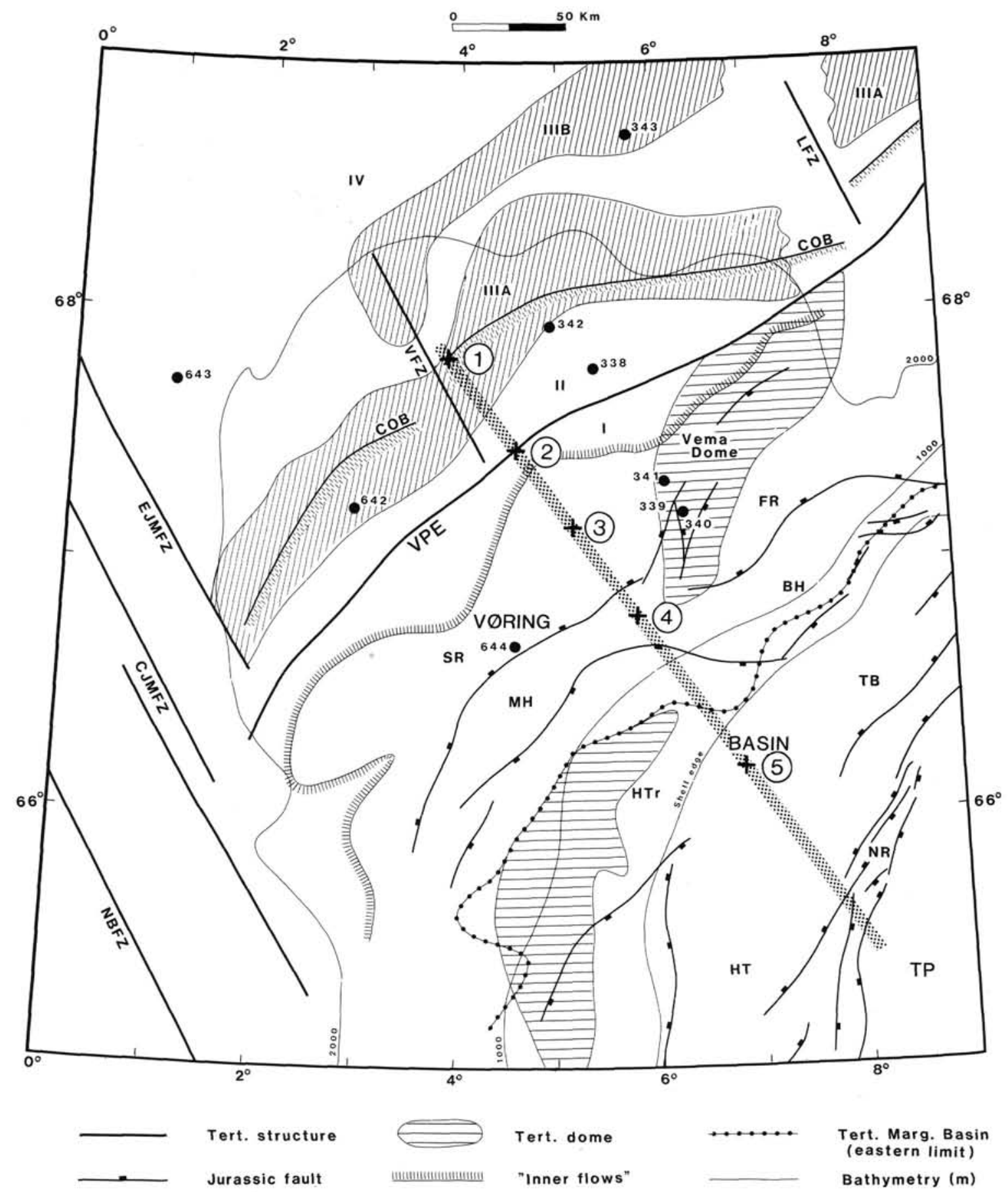

Figure 2. Structural map at the early Tertiary basalt level including oceanic fracture zones at the Vøring Plateau and adjacent areas. Position of seismic cross section and locations 1 to 5 referred to in the text are shown. DSDP/ODP drill sites are designated by solid circles. Main Mesozoic structural lineaments in the Vøring Basin and Trøndelag Platform are from Skogseid and Eldholm (this volume), Bukovics and Ziegler (1985), and Hagevang and Rønnevik (1986). Zones: I-inner flows; IItransitional crust; III A and B-dipping reflectors; IV-oceanic crust. VFZ, Vøring Fracture Zone; LFZ, Lofoten Fracture Zone; EJMFZ, East Jan Mayen Fracture Zone; CJMFZ, Central Jan Mayen Fracture Zone; NBFZ, Norway Basin Fracture Zone; TP, Trøndelag Platform; VPE, Vøring Plateau Escarpment; NR, Nordiand Ridge; TB, Traen Basin; MH, Molde High; BH, Bodø High; HT, Halten Terrace; HTr, Halten Trough; FR, Fleina Rift; SR, Smøla Rift. From Skogseid and Eldholm (this volume).

ments at the time of initial rifting. To visualize the actual relative crustal movements at initial rifting, we loaded our preferred model B, as well as model A, with the sediment thicknesses in Table 2 after decompaction (Fig. 6). As the lithosphere was stretched and uplifted, the sediments were initially raised to 900 $m$ above sea level. Subsequent erosion would then potentially reduce the sediment thickness by a maximum of $2500 \mathrm{~m}$ (Pedersen, 1987), depending on the rate of thermal subsidence. 


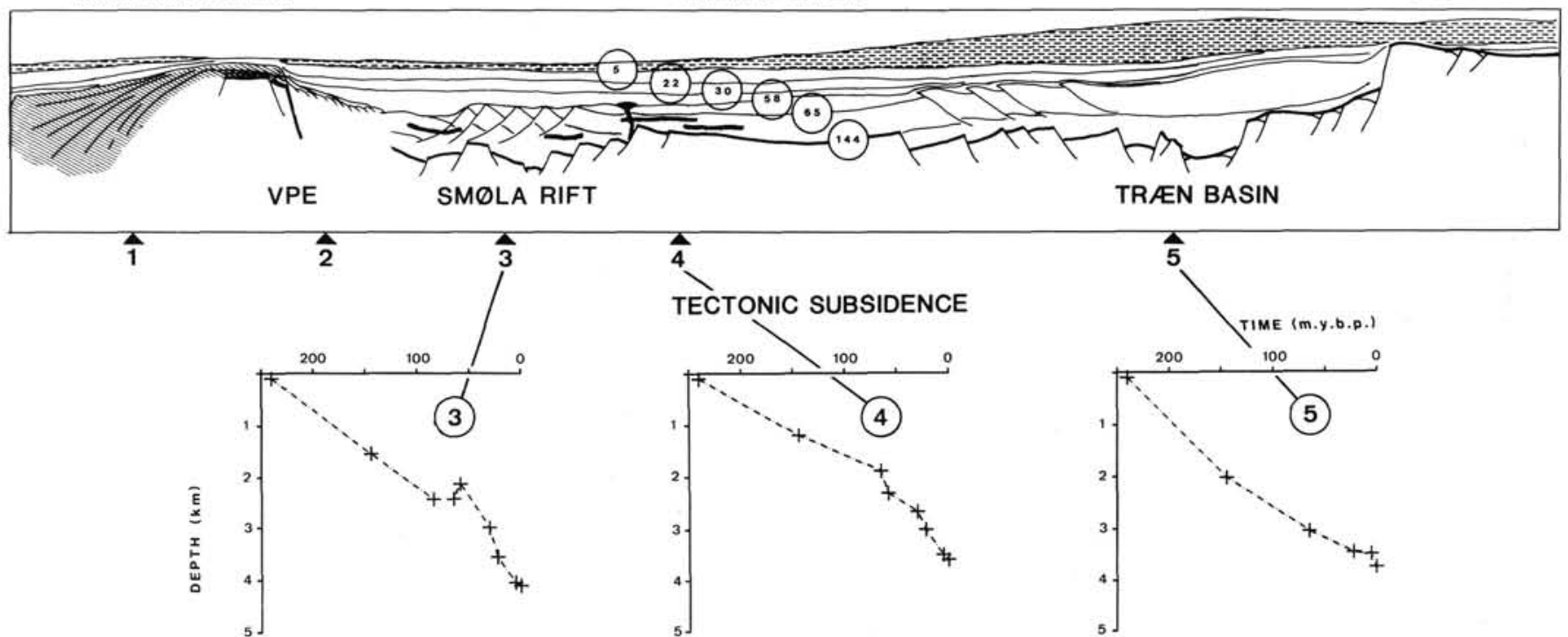

Figure 3. Schematic seismic cross section of the Vøring Margin. Locations 1 to 5 are shown. Horizons are numbered according to age, and the postMiocene sequence has been shaded. The sequence of dipping reflectors is seen underneath the Vøring marginal high. Tectonic subsidence curves are computed at locations 3,4 , and 5 .

Table 2. Stratigraphic data for locations 3 (a), 4 (b) and 5 (c). Horizon and paleowater depths based on the seismic interpretation of Skogseid and Eldholm (this volume). Sea-level changes from Watts and Steckler (1979) and Watts and Thorne (1984).

\begin{tabular}{|r|r|r|c|}
\hline Age & Horizon depth & Paleowater depth & Sea-level change \\
\hline $\mathrm{Ma}$ & $\mathrm{m}$ & $\mathrm{m}$ & $\mathrm{m}$ \\
\hline 0 & 0 & 1430 & 0 \\
5 & 360 & 1430 & 0 \\
22 & 620 & 1000 & 20 \\
30 & 940 & 500 & 25 \\
58 & 1660 & 0 & 100 \\
144 & 4810 & 300 & 80 \\
240 & 6560 & 100 & 0 \\
\hline
\end{tabular}

A

\begin{tabular}{|r|r|r|c|}
\hline Age & Horizon depth & Paleowater depth & Sea-level change \\
\hline $\mathrm{Ma}$ & $\mathrm{m}$ & $\mathrm{m}$ & $\mathrm{m}$ \\
\hline 0 & 0 & 1220 & 0 \\
5 & 400 & 1200 & 0 \\
22 & 800 & 800 & 20 \\
30 & 970 & 500 & 25 \\
58 & 1140 & 200 & 100 \\
65 & 1980 & 0 & 100 \\
144 & 3800 & 0 & 80 \\
240 & 5550 & 100 & 0 \\
\hline
\end{tabular}

\begin{tabular}{|r|r|r|c|}
\hline Age & Horizon depth & Paleowater depth & Sea-level change \\
\hline Ma & $\mathrm{m}$ & $\mathrm{m}$ & $\mathrm{m}$ \\
\hline 0 & 0 & 340 & 0 \\
5 & 1500 & 340 & 0 \\
22 & 1700 & 340 & 20 \\
65 & 2000 & 0 & 100 \\
144 & 6500 & 300 & 80 \\
240 & 9200 & 100 & 0 \\
\hline
\end{tabular}

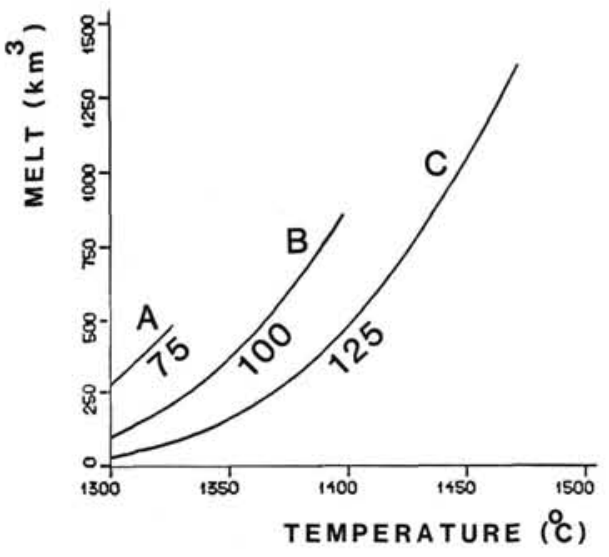

Figure 4. Total melt generation computed from the inferred $\beta$ distribution across the margin for three lithospheric models with varying thickness, $h_{l}$ and and basal temperature, $T_{h l}$. Model A: $T_{h l} / h l=1325 / 75$; B: 1385/100; C: $1445 / 125\left({ }^{\circ} \mathrm{C} / \mathrm{km}\right)$.

\section{DISCUSSION}

A critical parameter in the modeling procedure presented above is the $\beta$ distribution across the margin. We consider the $\beta$ estimates in the outer Vøring Basin (locations 3 and 4) to be reasonably accurate, whereas the estimates for the Vøring Plateau Escarpment and continent/ocean boundary (locations 1 and 2) are poorly constrained. Actually, the latter might have been $100 \%$ higher (Le Pichon and Sibuet, 1981; England, 1983). This would increase the calculated amounts of melt production and relative uplift for each of the models investigated. For example, a significant $\beta$ increase in model $\mathrm{B}$ would produce more melt than estimated for this margin (Fig. 4). Thus, our preferred lithospheric thickness and base temperature might be maximum estimates.

Another uncertainty in the modeling is the estimated volume of produced basalts. We have used a wide range of acceptable values, probably including the correct one. 


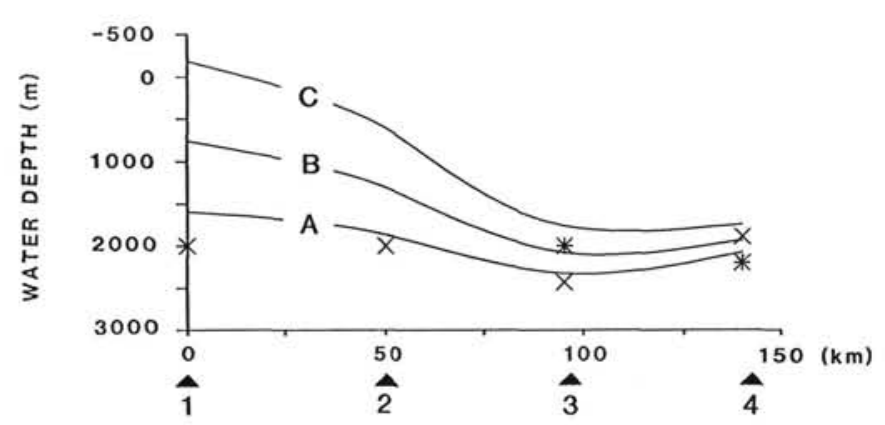

Figure 5. Depth to the water-loaded basement surface (pre-rifting tectonic subsidence plus initial subsidence/uplift (calculated for the initial rifting based on the pre-rift water depths shown by crosses). A, B, and C refer to the three lithospheric models in Figure 4. Stars are the values inferred from the tectonic subsidence curves at $58 \mathrm{Ma}$, allowing for thermal subsidence since $65 \mathrm{Ma}$.

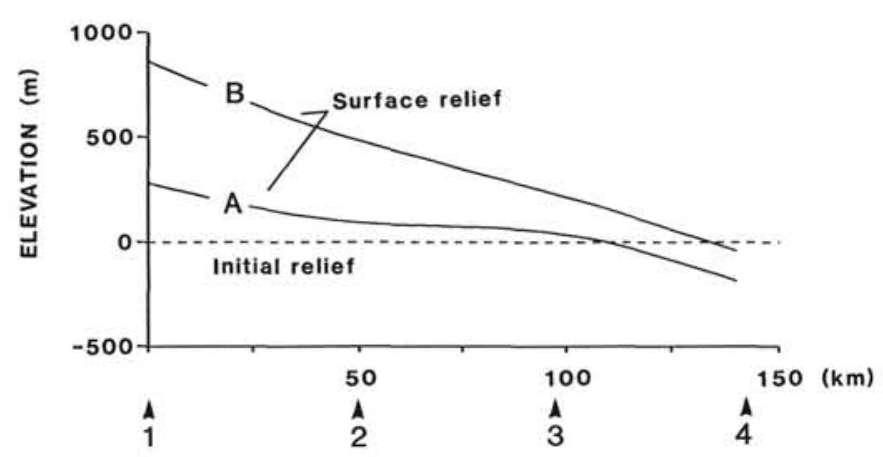

Figure 6. Surface relief after stretching when the sediment load is taken into account for models A and B. The surface is at sea level prior to rifting.

Our modeling procedure assumes that all the magma has migated upward from the zone of melting. This assumption is not unreasonable as basaltic melt migration is a very effective process (McKenzie, 1985).

In terms of proposed models for the evolution of rifted volcanic continental margins we believe that our results, although obtained for the Vøring Margin only, bear some general implications. Hinz et al. (1987), Mutter et al. (1988), and Mutter and Zehnder (1988) suggested that in a zone of previously weakened lithosphere, rifting affects a narrow area. According to Buck (1986), a narrow rift initiates induced convective cells within the upper mantle because of the large lateral thermal gradient between the hot rift conduit and the adjacent cold lithosphere. The convection would bring additional material within melting $\mathrm{P} / \mathrm{T}$ conditions which result in an increased amount of liquid basalt produced. Our subsidence data, however, show that the narrow rift concept might not be applicable at the Vøring Margin where we have documented that rifting affected a wide region (approx. 150-200 km). The convection approach does not seem to apply to wider rifts (Mutter et al., 1988).

White et al. (1987), on the other hand, have considered the development of volcanic margins in relation to thermal anomalies or hot spots in the asthenosphere. They argue that the only difference between volcanic and nonvolcanic margins is that the temperature at the base of the lithosphere is $100-150^{\circ} \mathrm{C}$ higher under the incipient volcanic margin than beneath a nonvolcanic one. Our modeling results suggest that the magnitude of the thermal anomaly might be much smaller. The thermal anomaly need not exceed about $50^{\circ} \mathrm{C}$ to maintain sufficient magma production and cause initial uplift. This is in agreement with inde- pendent estimates by Cochran and Talwani (1978). From a study of the North Atlantic Ocean depth and gravity anomalies, they computed an upper asthenospheric density deficiency of $6 \mathrm{~kg}$ / $\mathrm{m}^{3}$. This corresponds to a present-day increased temperature of about $50^{\circ} \mathrm{C}$ if a thermal expansion coefficient of $0.00003 \mathrm{k}^{-1}$ is used (Foucher et al., 1982). Thus, the temperature anomaly appears to be of a regional and time-continuous character.

\section{SUMMARY AND CONCLUSIONS}

A subsidence model incorporating partial melting has been applied to the Vøring Plateau Margin. From interpreted seismic sections we have computed the tectonic subsidence as well as the amount of magma generation for various lithospheric models.

The computed tectonic subsidence curves at three locations in the Vøring Basin reveal that the Vøring Margin experienced at least two prominent rift phases. The early Tertiary rifting phase, immediately preceding the Norwegian-Greenland Sea opening, affected a broad zone extending into the Vøring Basin over a lateral distance of more than $150 \mathrm{~km}$. Thus, the concept of a nonextensional volcanic margin appears not to be valid for this region.

The process of partial melting in the ascending upper mantle, associated with lithospheric stretching, can account for the formation of volcanic passive margins. Our results show that only a minor temperature anomaly is required at the base of the lithosphere to explain the volume of basaltic magma produced and the amount of initial uplift induced in the case of the formation of the Vøring Plateau Volcanic Margin.

\section{ACKNOWLEDGMENTS}

We thank J. P. Foucher and A. B. Watts for critical review of the manuscript. Thanks are also due Olav Eldholm, Hans Egil Ro, and the members of the Marine Geophysics Research Group at the Department of Geology, University of Oslo, for helpful discussions.

\section{REFERENCES}

Ahern, J. L., and Turcotte, D. L., 1979. Magma migration beneath an ocean ridge. Earth Planet. Sci. Lett., 45:115-122.

Buck, W. R., 1986. Small-scale convection induced by passive rifting: the cause for uplift of rift shoulders. Earth Planet. Sci. Lett., 77: 362-372.

Bukovics, C., and Ziegler, P. A., 1985. Tectonic development of the mid-Norway continental margin. Mar. Pet. Geol., 2:2-22.

Bukovics, C., Shaw, D. N., Cartier, E. G., and Ziegler, P. A., 1984. Structure and development of the mid-Norway continental margin. In Spencer, A. M., et al. (Eds.), Petroleum Geology of the North European Margin: London (Graham and Trotman), 407-424.

Cochran, J. R., and Talwani, M., 1978. Gravity Anomalies, Regional Elevation, and the Deep Structure of the North Atlantic. J. Geophys. Res., 83:4907-4924.

Cox, K. G., Bell, J. D., and Pankhurst, R. J., 1979. The Interpretation of Igneous Rocks: London (George Allen and Unwin Ltd.).

Eldholm, O., Thiede, J., Taylor, E., et al., 1987. Proc. ODP, Init. Repts., 104: College Station, TX (Ocean Drilling Program).

Eldholm, O., Thiede, J., Taylor, E., and Shipboard Scientific Party, 1987. Summary and preliminary conclusions, ODP Leg 104. In Eldholm, O., Thiede, J., Taylor, E., et al., Proc. ODP, Init. Repts., 104:751-771.

England, P., 1983. Constraints on extension of continental lithosphere. J. Geophys. Res., 88:1145-1152.

Foucher, J.-P., Le Pichon, X., and Sibuet, J.-C., 1982. The ocean-continent transition in the uniform lithospheric stretching model: role of partial melting in the mantle. Philos. Trans. R. Soc. London, A 305: 27-43.

Guidish, T. H., Kendall, C. G. S. C., Lerche, I., Toth, D. J., and Yarzab, R. F., 1985. Basin evaluation using burial history calculations: an overview. $A A P G$ Bull., 69:92-105.

Hagevang, T., and Rønnevik, H. C., 1986. Basin development and hydrocarbon occurrence offshore mid Norway. Mem. Am. Assoc. Pet. Geol., 40:599-613.

Hinz, K., 1981. A hypothesis on terrestrial catastrophes. Wedges of very thick oceanward dipping layers beneath passive continental mar- 
gins-their origin and paleoenvironmental significance. Geol. Jahrb., E 22:3-28.

Hinz, K., Dostman, H. J., and Hanisch, J., 1984. Structural elements of the Norwegian continental margin. Geol. Jahrb., A 75:193-221.

Hinz, K., Mutter, J. C., Zehnder, C. M., and the NAT Study Group, 1987. Symmetric conjugation of continent-ocean boundary structures along the Norwegian and East Greenland margins. Mar. Pet. Geol., 4:167-187.

Hollander, N. B., 1984. Geohistory and hydrocarbon evaluation of the Haltenbanken area. In Spencer, A. M., et al. (Eds.), Petroleum Geology of the North European Margin: London (Graham and Trotman), 383-388.

Knox, R.W.O'B., 1988. The timing and significance of the early Palaeogene pyroclastic events in the North Sea Basin. In Morton, A. C. and Parson, L. M. (Eds.), Early Tertiary Volcanism. Spec. Publ. Geol. Soc. London, 39:407-419.

Le Pichon, X., and Sibuet, J.-C., 1981. Passive margins: A model of formation. J. Geophys. Res., 81:239-256.

Le Pichon, X., Angelier, J., and Sibuet, J.-C., 1982. Plate boundaries and extensional tectonics. Tectonophysics, 81:239-256.

McKenzie, D., 1978. Some remarks on the development of sedimentary basins. Earth Planet. Sci. Lett., 74:25-32.

McKenzie, D., 1985. The extraction of magma from the crust and mantle. Earth Planet. Sci. Lett., 74:81-91.

Morton, A. C., and Taylor, P. N., 1987. Lead isotope evidence for the structure of the Rockall dipping-reflector passive margin. Nature, 326:381-383.

Mutter, J. C., and Zehnder, C. M., 1988. Deep crustal structure and magmatic processes: the inception of seafloor spreading in the Norwegian-Greenland Sea. In Morton, A. C., and Parson, L. M. (Eds.), Early Tertiary Volcanism. Spec. Publ., Geol. Soc. London, 39:3548.

Mutter, J. C., Talwani, M., and Stoffa, P. L., 1982: Origin of seaward dipping reflectors in oceanic crust off the Norwegian margin by subaerial sea-floor spreading. Geology, 10:353-357.

Mutter, J. C., Talwani, M., and Stoffa, P. L., 1984, Evidence for a thick oceanic crust adjacent to the Norwegian Margin. J. Geophys. Res., 89:483-502.

Mutter, J. C., Buck, W. R., and Zehnder, C. M., 1988. Convective partial melting 1. A model for the formation of thick basaltic sequences during the initiation of spreading. J. Geophy. Res., 93:1031-1048.

Parsons, B., and Sclater, J. G., 1977. An analysis of the variations of ocean floor bathymetry and heat flow with age. J. Geophys. Res., $82: 803-827$.
Parsons, B., and Sclater, J. G., 1977. An analysis of the variations of ocean floor bathymetry and heat flow with age. J. Geophys. Res., 82:803-827.

Pedersen, T., 1987. A computer-based approach to basin analysis [Cand. Sci. thesis]. University of Oslo, Norway.

Roberts, D. G., Backman, J., Morton, A. C., Murray, J. W., and Keene, J. B., 1984. Evolution of volcanic rifted margins: Synthesis of Leg 81 results on the west margin of Rockall Plateau. In Roberts, D. G., Schnitker, D., et al. (Eds.), Init. Repts. DSDP, 81: Washington (U.S. Govt. Printing Office), 883-911.

Roberts, D. G., Schnitker, D., et al., 1984. Init. Repts. DSDP, 81: Washington (U.S. Govt. Printing Office).

Sawyer, D. S., 1985. Total tectonic subsidence: a parameter for distinguishing crust type at the U. S. Atlantic continental margin. J. Geophys. Res., 90:7751-7769.

Sclater, J. G., and Christie, P.A.F., 1980. Continental stretching: An explanation of the post-Mid-Cretaceous subsidence in the central North Sea basin. J. Geophys. Res., 85:3711-3739.

Skogseid, J., and Eldholm, O., 1987. Early Cenozoic crust at the Norwegian continental margin and the conjugate Jan Mayen Ridge. $J$. Geophys. Res., 92:11471-11491.

Smythe, D. K., 1983. Faeroe-Shetland Escarpment and continental margin north of the Faeroes. In Bott, H.M.P., Saxov, S., Talwani, M., and Thiede, J. (Eds.), Structure and Development of the GreenlandScotland Ridge: New York (Plenum Publishers), 109-120.

Watts, A. B., and Ryan, W.B.F., 1976. Flexure of the lithosphere and continental margin basins. Tectonophysics, 36:25-44.

Watts, A. B., and Steckler, M. S., 1979. Subsidence and eustasy at the continental margin of eastern North America. Maurice Ewing Symp. Series 3:, Washington, D.C. (American Geophysical Union), 218234.

Watts, A. B., and Thorne, J., 1984. Tectonics, global changes in sea level and their relationship to stratigraphical sequences at the U. S. Atlantic continental margin. Mar. Pet. Geol., 1:319-339.

White, R. S., Spence, G. D., Fowler, S. R., McKenzie, D. P., Westbrook, G. K., and Bowen, A. N., 1987. Magmatism at rifted continental margins. Nature, 330:439-444.

Yoder, H. S., Jr., 1976. Generation of Basaltic Magma: Washington, D.C. (National Academy of Sciences).

Date of initial receipt: 2 March 1988

Date of acceptance: 4 June 1988

Ms 104B-201 